\title{
Vai ter excursão? - Futebol de várzea, lazer popular e patrimônio cultural em Belo Horizonte (anos 1940-1980)
}

\author{
Raphael Rajão Ribeiro* \\ ORCID iD 0000-0001-7057-8367 \\ Museu Histórico Abílio Barreto, Fundação Municipal de Cultura, Belo Horizonte, Brasil
}

Resumo: O presente artigo objetiva examinar a realização de excursōes por clubes de futebol de várzea de Belo Horizonte e sua inserção em uma cultura esportiva popular, assim como suas relaçóes com o lazer entre populaçóes da periferia da capital mineira entre os anos 1940 e 1980. Esse é um dos temas que aparece em uma série de relatos orais produzidos como parte do inventário do futebol amador na cidade, ação que visou o reconhecimento da prática como patrimônio imaterial do município. O conteúdo das entrevistas, associado a fontes jornalísticas e à documentação das agremiaçôes, proporciona indícios para a compreensão dos sentidos alcançados pelas partidas que as equipes disputavam em outras localidades, fora da capital mineira. Tais jogos se articulavam aos esforços de auto-organização das entidades varzeanas e às possibilidades de diversão dos moradores dos bairros periféricos de Belo Horizonte naquele período.

Palavras-chave: Futebol amador. Excursões. Lazer. Belo Horizonte. Patrimônio imaterial.

\section{Will there be a tour? - Grassroots football, popular leisure and cultural heritage in Belo Horizonte (1940s-1980s)}

Abstract: This paper aims to examine the tours by grassroots football's clubs from Belo Horizonte and its bond with a popular sportive culture, as well its relations with the leisure among working class populations in Minas Gerais' capital city between the 1940s and the 1980s. This is one of the themes that emerge from a series of oral reports produced during the amateur football's inventory in the city, initiative that aims to recognize this practice as intangible heritage of the town. The content of the interviews, combined with press sources and clubs records, provide evidences to understand meanings achieved by these matches disputed by the teams in other towns, outside the capital city. Those matches are articulated

Doutor em História, Política e Bens Culturais pela Escola de Ciências Sociais (CPDOC-FGV). E-mail: raprajao@gmail.com. 
with clubs' self-management efforts and entertainment alternatives for the residents in working classes neighborhoods in Belo Horizonte in that time.

Keywords: Amateur football. Tours. Leisure. Belo Horizonte. Intangible heritage.

\section{Introdução}

O futebol já era praticado por agremiaçôes situadas nos bairros suburbanos de Belo Horizonte $(\mathrm{MG})$, onde vivia a maior parte da população trabalhadora, desde os anos iniciais de sua prática na cidade (Ribeiro, 2018, p. 79). Nas primeiras décadas do século $\mathrm{XX}$, os chamados "clubes menores" ocupavam posiçôes secundárias em competiçôes protagonizadas pelas equipes tradicionais da capital mineira, as quais dominavam a organização daquela modalidade esportiva, a exemplo do América e do Atlético (Mayor, 2017, p. 166). Foi entre os anos 1930 e 1940 que, do ponto de vista da organização desportiva, consolidou-se uma diferenciaçáo mais clara entre essas associaçóes. Essa foi impulsionada por processos como a oficialização do profissionalismo dos atletas, a partir de 1933 (Gomes; Pinheiro, 2015), e a criação de um sistema nacional de desportos, com a edição do Decreto-Lei n ${ }^{\circ} 3.199$, de 14 de abril de 1941 (Linhales, 1996, p. 85-110), que teve como consequência a reestruturação da Federação Mineira de Futebol (FMF), com a criação, em 1942, de um Departamento de Futebol Amador (DFA) voltado para as entidades que não aderiram à regulamentaçáo do pagamento de salários aos jogadores (DFA..., 1956).

A partir desse período, uma separação que já se delineava com a existência de duas divisóes no campeonato da cidade era consolidada com a constituiçấo de dois circuitos (Damo, 2018, p. 49; Myskiw, 2012, p. 45) distintos. Um deles ficou restrito ao futebol de espetáculo, com clubes que aderiram ao regime profissional, e o outro, que se convencionou chamar de "várzea", concentrou uma grande variedade de agremiaçốes que não oficializaram a remuneração de jogadores. Esse segundo grupo reunia um contingente heterogêneo de associaçôes formadas a partir de vínculos vicinais, classistas, de parentesco e de amizade, com entidades que possuíam boa infraestrutura e extensos quadros de sócios, por um lado, e outras que se resumiam a um punhado de atletas e a um jogo de camisas, por outro. Apesar da discrepância, todas essas equipes faziam parte do mesmo universo, na medida em que se conectavam por meio de uma diversidade de disputas, oficiais ou auto-organizadas, que as inseriam em um mesmo circuito, comumente chamado de "várzea" de Belo Horizonte.

O presente artigo propóe-se a examinar uma dessas formas de disputas autoorganizadas pelos clubes amadoristas da capital mineira: as excursóes. Esse era o nome que se dava a qualquer partida que extrapolasse o circuito municipal, independente 
da distância da cidade a ser visitada. Tais certames permitiam a conexão das equipes belo-horizontinas com outras localidades, em sua maioria dentro do próprio estado de Minas Gerais, mas não restritas a ele. No esforço cotidiano dos sujeitos varzeanos de manterem um calendário ininterrupto de fins de semana preenchidos com jogos, essas contendas criavam possibilidades de embates absorventes (Geertz, 1989, p. 185213), normalmente em campos com melhores condiçóes do que os da capital mineira, além de tornarem-se opção de lazer e turismo para as comunidades formadas em torno das agremiaçóes. As histórias decorrentes dessas viagens ocupam lugar especial nas memórias compartilhadas pelos integrantes das associaçóes atléticas populares e estáo presentes em suas narrativas orais, como será abordado mais adiante.

\section{Inventário do futebol amador em Belo Horizonte e usos da história oral}

A presença de relatos sobre as excursóes ficou bem demarcada no conjunto de entrevistas produzido durante a realização do "Inventário do futebol amador em Belo Horizonte”, entre os anos de 2016 e 2018. A iniciativa articulada pela Fundação Municipal de Cultura (FMC) da capital mineira, por meio da então Diretoria de Patrimônio Cultural e Arquivo Público (DPCAP), e pela Secretaria Municipal de Esportes e Lazer (Smel), tinha por objetivo reunir informaçóes sobre essa vertente popular da modalidade na cidade. Tal ação era uma resposta a demandas vocalizadas, especialmente, pela Câmara de Vereadores que, no início de 2016, aprovou o Projeto de Lei $n^{\circ} 1.634 / 2015$. Este tinha a seguinte ementa: "Autoriza o Executivo a criar o programa de preservaçáo, revitalização e tombamento de Campos de Futebol de Várzea no Município" (CMBH, 2015). Apesar da votação favorável na casa legislativa, a proposição foi vetada pelo prefeito, sob alegação de que tal competência era privativa do Conselho Deliberativo do Patrimônio Cultural do Município (CDPCM), a quem cabia a definição de políticas dessa natureza (Belo Horizonte, 2016).

Mesmo com o veto, a tramitação do projeto reforçava demanda que era apresentada à DPCAP desde 2011, quando uma proposição de lei semelhante recebeu parecer do órgáo. Nessa medida, uma equipe que reuniu técnicos dos setores da cultura, dos esportes e do lazer foi montada para o desenvolvimento de um inventário do futebol amador, o qual se concentrou em agremiaçôes e/ou campos que se mantinham em atividade há mais de 50 anos, com um total de 33 locais e 39 entidades identificadas dentro desse perfil ao final do processo. Tal esforço visava o reconhecimento da prática como patrimônio imaterial do município, sendo que a primeira etapa da patrimonialização, com a autorizaçáo para a abertura do registro, se deu em dezembro de 2017, conforme deliberação do CDPCM (Belo Horizonte, 2018). A conferência definitiva da proteção segue, contudo, pendente de votação, apesar de o dossiê sobre o tema ter sido finalizado 
ainda em 2018.

Levando-se em conta a natureza da manifestação e as metodologias propostas para a produção de inventários do patrimônio imaterial (Iphan, 2000), o levantamento se compôs de pesquisas de campo, consultas a acervos documentais, rodas de debate com a comunidade interessada, assim como lançou mão da produção de relatos gravados. A incorporaçáo da história oral em iniciativas do tipo náo é novidade (Guillen, 2018). No caso em questáo, ela contribuiu com narrativas que permitiram examinar as trajetórias das entidades e dos espaços ocupados pela prática do futebol amador, com a percepção da constituição de uma cultura esportiva própria, a qual era compartilhada pelas comunidades formadas em torno dos clubes e que se transformava frente às mudanças de contextos urbanos, geracionais e tecnológicos.

Com o objetivo de gerar registros sobre a trajetória das entidades e dos lugares inventariados, as entrevistas possuíram um recorte temático (Alberti, 2005, p. 37-41), com a adoçáo de roteiros semiestruturados. $\mathrm{O}$ mais usual foi a produção de relatos com uma dupla de narradores, sendo um deles um membro atual da agremiação, no mais das vezes o seu presidente, e uma figura histórica da entidade, em muitos casos, reconhecida como fundador da associaçáo. Ainda que tal escolha pudesse implicar em interferências de um dos participantes sobre a fala do outro (Portelli, 2010, p. 1935), tratou-se de uma rica experiência que permitiu, inclusive, o compartilhamento de memórias ou referências, por inúmeras vezes, desconhecidas pelo outro depoente. A diacronia que atravessava as entrevistas propiciou a observaçáo de mudanças e permanências da cultura esportiva popular gestada a partir do futebol de várzea, bem como dos meios pelos quais os saberes eram transmitidos entre os sujeitos integrantes daquele circuito.

Ao final de pouco menos de dois anos de pesquisa, formou-se um conjunto de 49 entrevistas, que totalizavam aproximadamente 60 horas de gravação. Os registros digitais, bem como a transcrição do material, originalmente comporiam o acervo do Centro de Memória do Esporte e do Lazer (Cemel), sediado na Secretaria Municipal de Esportes e Lazer. Contudo, uma mudança de planos da gestáo levou à desativaçáo do setor e, como consequência, o material encontra-se em processo de recolhimento pelo Arquivo Público da Cidade de Belo Horizonte (APCBH) e terá sua guarda permanente associada ao Fundo Secretaria Municipal de Esportes e Lazer.

As narrativas a serem tratadas neste artigo, portanto, compóe um conjunto de relatos produzido com finalidades diversas das quais servirão para a análise que se pretende aqui, uma vez que seu objetivo original era o fornecimento de dados para a elaboraçáo de um inventário com vistas ao reconhecimento e à proteçáo de uma prática cultural. Agora integrantes de um acervo, passam a compor aquilo que, na maioria das vezes, tem se convertido num "patrimônio silencioso", conforme reflexão de Luciana Heymann e Verena Alberti (2018, p. 11-29). Sua utilização implica, portanto, na percepção do deslocamento de sentidos imposto por essa operaçáo, o que foi levado em 
conta ao se fazer a crítica documental dos conteúdos trabalhados a seguir.

Considerando-se os objetivos deste texto, os relatos componentes do conjunto acima descrito serão articulados às referências jornalísticas do Diário da Tarde, vespertino publicado pelos Diários Associados, que tinha um perfil mais popular em relação ao Estado de Minas, título da mesma empresa. Com a valorização de notícias esportivas, policiais e do cotidiano da cidade, aquele periódico é reconhecido pelos integrantes das agremiações como o que, por décadas, dedicou mais espaço ao tema, sendo não apenas um divulgador, mas também um patrocinador e promotor de iniciativas direcionadas à várzea. Ademais, serão cotejados documentos mantidos pelos clubes amadores em seus acervos, os quais oferecem interessantes indícios sobre a realização das excursões pelas equipes belo-horizontinas.

Ainda que seja uma prática que tenha atravessado as décadas e ainda hoje desempenhe um papel importante na constituição do calendário competitivo das agremiaçóes da capital mineira, o fenômeno será examinado entre os anos de 1940 e 1980. Trata-se de um momento de conformação de um circuito da várzea na cidade, quando as disputas auto-organizadas tinham uma centralidade no conjunto das partidas protagonizadas pelas equipes. $\mathrm{O}$ surgimento de novos torneios oficiais a partir da década de 1990 e a maior circularidade de jogadores entre equipes de Belo Horizonte e aquelas da regiáo metropolitana, dentre outros fatores, impactaram na forma de organização da série de contendas. Percebe-se um gradual abandono da ideia dos fins de semana ininterruptos preenchidos por jogos e a perda da força simbólica dos embates autogeridos, não mais vistos como tăo absorventes.

\section{Excursões varzeanas: tradição futebolística, lazer e cultura esportiva popular}

A difusão do futebol como informação e prática cultural é indissociável da circulação de pessoas, informaçóes e mercadorias no globo e no Brasil entre a segunda metade do século XIX e o início do XX (Mascarenhas, 2014, p. 49-101). Nessa medida, a mobilidade das equipes e o seu intercâmbio, com a promoçáo de partidas entre times de localidades diferentes, é constituinte do próprio fenômeno e da forma como ele proliferou pelo planeta. No caso belo-horizontino, poucos meses separam a criaçáo do primeiro clube da modalidade e a realizaçáo da excursão inaugural de uma equipe ao interior do estado, já em 1905 (Ribeiro, 2018, p. 56).

Os deslocamentos das equipes para a disputa de partidas e a ampliação dessas distâncias ocorriam pari passu à criação de facilidades impostas pelo desenvolvimento dos meios de transporte eà conformaçáo de um circuito regional, nacional e internacional do futebol de espetáculo (Damo, 2014). O aumento do interesse pelo estilo brasileiro 
de se praticar a modalidade e dos investimentos no esporte criou a possibilidade de clubes nacionais realizarem turnês pela Europa já na década de 1920 (Hollanda, 2020, p. 29-40). O crescimento dos custos para a manutenção das agremiaçóes estimulava a busca de rendas com a circulaçáo dos times (Santos, 2010, p. 362-367), de modo que, por décadas, essa foi uma forma de disputa bastante recorrente entre os clubes brasileiros mais tradicionais, até que um calendário de competiçóes se consolidasse na segunda metade do século XX e deixasse pouco espaço para a realização de viagens avulsas (Damo, 2014, p. 42-54).

Excursóes futebolísticas não se prestavam apenas ao preenchimento de datas livres e ao financiamento das atividades das equipes do futebol de espetáculo, eram também oportunidades para a afirmaçáo do desenvolvimento esportivo, cultural e social dos meios atléticos e das localidades em circulaçáo. Visitantes e anfitrióes esforçavam-se para transmitir uma boa imagem, o que se manifestava desde a formação da delegação - muitas vezes denominada "embaixada" - até a promoção de um bem cuidado cerimonial, que podia incluir a oferta de banquetes aos convidados. Tais práticas nunca foram integralmente abandonadas, ainda que fossem mais comuns nas primeiras décadas do século $\mathrm{XX}$, quando um tom aristocrático imperava entre os clubes (Ribeiro, 2018, p. 133-134; Hollanda, 2020, p. 32-33). As turnês de times profissionais também poderiam cumprir agendas políticas, servindo a interesses institucionais ou estatais, permitindo intercâmbios e entendimentos entre dirigentes esportivos e demais autoridades (Burlamaqui, 2020, p. 284-302; Santos, 2019).

Nessa perspectiva, quando se trata da realização de excursões no circuito do futebol de espetáculo, observa-se que a fórmula inicialmente adotada para o intercâmbio esportivo e para o preenchimento de datas disponíveis, passa a também a responder a uma demanda de arrecadaçáo pelos clubes, incluindo a constituição de empresários especializados na venda de jogos (Burlamaqui, 2020, p. 284-302). Com a estruturação de um calendário de competiçôes regulares, esse tipo de disputa perde espaço e se torna mais eventual. Tais transformaçóes se articulam à configuraçáo de um mercado abrangente, com a crescente difusão televisa dos certames.

No que se refere à prática esportiva desenvolvida por clubes integrantes de um circuito varzeano, ainda que processos similares possam ser identificados, eles inserem-se numa dinâmica específica, que respondia a outras demandas e a formas de organização vinculadas a grupos sociais que partilhavam de valores e expectativas diversos em relação ao esporte. Se o Departamento de Futebol Amador da Federação Mineira de Futebol, criado no início dos anos 1940, é responsável, desde então, pela promoção de um campeonato municipal oficial dedicado aos clubes amadoristas, foram, principalmente, as pelejas organizadas pelas próprias entidades que responderam pela estruturação da maior parte do calendário de jogos que movimentava a várzea de Belo Horizonte a cada final de semana entre as décadas de 1940 e 1980.

Essas disputas, grosso modo, reuniam cinco formas mais recorrentes: amistosos, 
festivais esportivos, torneios avulsos, partidas festivas e excursóes. Todas elas organizadas diretamente pelos clubes amadoristas, ainda que acompanhadas pelo DFA, no caso do envolvimento de equipes filiadas. Eram principalmente esses certames autogeridos que compunham um calendário que mobilizava os esforços dos dirigentes varzeanos para que cada final de semana fosse preenchido com alguma atividade, de modo a garantir a diversão de jogadores e da comunidade que se articulava em torno das agremiaçôes.

É nessa perspectiva que as excursóes se inserem. Questôes como o desejo dos jogadores circularem por outras localidades, a importância de partidas fora para a ocupaçáo dos fins de semana, as dificuldades para articulaçáo das viagens e o engajamento da comunidade local para tomar parte nos passeios são alguns dos tópicos narrados em relatos orais de integrantes dos clubes amadoristas de Belo Horizonte. Como indicou Alessandro Portelli, os esportes são um campo privilegiado para a construção de identidades locais e de classe, sendo um tema forte nas memórias de trabalhadores e moradores de bairros populares (2010, p. 131-158).

A realização de excursóes podia se originar de convites que eram encaminhados diretamente aos clubes ou de anúncios publicados nas páginas dos jornais, a exemplo do Diário do Tarde, quando eram indicadas as condiçóes oferecidas pelos anfitriôes (Qual..., 1949). Se havia um desejo das equipes do interior em receber as agremiaçóes da capital, o interesse do intercâmbio tendia a ser recíproco, como aponta o relato de Denerval Martinho Rufino, o "Dinho", filho do fundador do Pastoril Futebol Clube:

Tinha o contrato, ajuda de custo e hospedagem. Porque aqui em Belo Horizonte, infelizmente, o pessoal gostava de viajar, na época, porque os campos de Belo Horizonte são todos carentes, não é, bicho? São todos campos de terra. Então, quando você falava com um neguinho que você ia para jogar em um tapete, em um campo gramado lá não sei onde, neguinho ficava doido pra ir. Na maioria das vezes, saía para jogar fora por causa dos gramados, náo é? (Denerval Martinho Rufino; João Pereira dos Santos, 2017).

Como indicado no relato de "Dinho", havia o desejo, entre os atletas belohorizontinos, de disputar partidas em campos gramados, que eram raros no meio varzeano local, onde prevalecia o piso de terra (Raimundo Expedito Fernandes, 2017). Além de oportunidade de desempenhar uma partida em uma cancha mais estruturada, jogos no interior poderiam se mostrar mais absorventes em comparação com amistosos contra times de pouco renome. Isso era o que evidenciava, por exemplo, o anúncio da seguinte excursão:

Deverá seguir domingo para a cidade de Pompeu [sic], onde dará combate ao quadro do Clube Atlético Pompeano, um dos melhores conjuntos do Oeste Mineiro, o Rosário Esporte Clube, vencedor da "Copa 10 anos" em um torneio de que tomaram parte os melhores quadros varzeanos da Capital. (O Rosário..., 1963). 
Recém-vencedor do torneio promovido por uma emissora local, a Rádio Itatiaia, em celebração aos seus dez anos, o Rosário Esporte Clube reafirmava seu prestígio, lançando-se em partida contra renomada equipe oeste mineira. A agremiação que, nos anos seguintes, se mostraria um time quase imbatível e conquistaria o posto de hexa campeão da competição promovida pelo DFA (O Rosário..., 1970), tornou-se a mais requisitada para certames pelo interior do estado.

Em outras formas de disputas autogeridas pelos clubes, como eram os amistosos, havia uma premissa de reciprocidade, por meio da prática mais comumente chamada de "pagar visita", que consistia no fato de que uma agremiação que recebesse uma equipe adversária em seu campo ficava com a obrigação de realização de uma partida contra o oponente no espaço de jogo dele (Manoel Lúcio Machado; Jailson Santos da Silva, 2018). Essa lógica de prestaçáo e contraprestação (Mauss, 2003, p. 183-314), incluído o uso da expressão "pagar visita", encontra paralelo em manifestaçóes religiosas de grupos afro-brasileiros, como são as festividades das irmandades de Nossa Senhora do Rosário (Vilarino, 2007, p. 10), o que aponta para o compartilhamento de formas de fazer entre uma expressáo popular do esporte e tradiçóes negras na capital mineira. Aproximação similar passava pela formalidade da confirmação do acordo por meio da redação de ofícios, verificada tanto na várzea quando no congado.

No caso das excursōes, a assimetria entre as condiçóes oferecidas pelos clubes do interior, detentores de campos gramados e instalaçôes mais confortáveis, dificultava a contraprestação às agremiaçôes da capital, que não teriam sua visita paga. Nessa medida, o mais comum era que o anfitriáo oferecesse uma ajuda de custo às equipes belo-horizontinas, para compensar parte do valor do transporte (José Maciel Campos, 2017). Essa quantia não era fixa e, no caso de equipes de destaque no circuito varzeano, em especial aquelas que alcançavam boas posiçóes nas competiçóes oficiais e tinham renome no meio, era muito plausível a realização de barganhas, em busca de rendimentos maiores. Esse era o caso, por exemplo, do já citado Rosário Esporte Clube que se utilizava, inclusive, das páginas do Diário da Tarde para responder pedidos de exibições vindos do interior e solicitar cachês mais altos (Lima, 1965).

Vale aqui pontuar um desequilíbrio observado no circuito da várzea que se articula à sua própria constituição. Como tratado anteriormente, esse universo de clubes não aderentes ao futebol de espetáculo abarcava uma heterogeneidade de agremiaçóes, com origens e condiçóes muito diversas entre si. Assim que, dentre eles, houve a conformação de uma elite que, por razóes variadas, dispunha de mais recursos e levava vantagens competitivas sobre os demais, incluindo a oferta de bonificaçôes financeiras aos atletas, recrutando os mais capacitados e, por vezes, disputando "pés de obra" com agremiaçóes profissionais de menor prestígio. Nessa medida, tais entidades sobressaíamse nas competiçóes, conquistando títulos, despertando o interesse de clubes do interior, que destinavam um sem número de convites para excursóes. Em muitas localidades, com pequenos estádios cercados e com bilheterias, a cobrança de ingressos se fazia 
possível, sendo economicamente interessante promover uma peleja que envolvesse times afamados de Belo Horizonte (Itaúna..., 1949). Todo esse cenário permitia que equipes como o Rosário Esporte Clube pudessem barganhar os valores, tanto para arcar com os custos mais altos de uma equipe que remunerava informalmente seus jogadores, como por saber que poderia garantir boas arrecadaçôes.

Esse, contudo, não era o cenário que prevalecia entre a maioria das equipes, de modo que, ainda que contasse com o custeio parcial do transporte, a viabilizaçáo da viagem dependia de um esforço nem sempre possível dos dirigentes, jogadores e da comunidade envolvida. É o que ressalta Jair Colen Filho, o "Lu", que foi presidente do Reunidos Esporte Clube, nos anos 1970:

[...] o detalhe é que pra você jogar fora de Belo Horizonte, a uma distância superior, vamos dizer assim, a 50 quilômetros, você precisa alugar um ônibus e para alugar um ônibus não é barato e para dividir o valor para todos os participantes, também, a condição financeira do pessoal da várzea normalmente não permite, os times que mais fizeram isso, eles tinham por trás a ajuda de empresários, que custeavam isso. (Jair Colen Filho, 2016).

"Ajuda de empresários" era com o que contava, por exemplo, o já citado Rosário Esporte Clube, mantido pelo dono de restaurante Rosário Scotelaro, grande patrono da agremiaçáo. Na tentativa de driblar os custos, várias eram as estratégias adotadas pela maioria dos times. No caso da locaçáo de ônibus, descontada a ajuda de custo, cotizavase o valor restante entre jogadores e torcedores (Maria da Conceição Silva; Eliana da Conceiçáa Costa; Carlos Pereira, 2017). Em trajetos mais curtos, para cidades vizinhas, podia-se apelar para os caminhóes. Como se recorda Raimundo Expedito Fernandes, comerciante, dono de bar, que viria a ser presidente da Associação Ferroviária Esportiva:

Eu lembro que inclusive em sessenta e oito... Sessenta e cinco, mais exato, eu estava fazendo quinze anos de idade, e a Ferroviária foi fazer uma excursão em Justinópolis. Olha bem, excursão em Justinópolis! Justinópolis hoje você vai até a pé. Foi uma viagem, aí eu fiquei até sonhando com aquilo, e todo mundo foi com um caminhão aberto, na época não tinha nada assim de segurança. E deve ter ido dentro de um caminhão Chevrolet Brasil, eu lembro perfeitamente disso, deve ter ido quase cem pessoas de pé, sem segurança, sem nada, e foi a primeira viagem que eu fiz com o futebol, para assistir a Ferroviária, e um time que chama Madureira, em Justinópolis. (Raimundo Expedito Fernandes, 2017).

O que poderia parecer precariedade para alguém de fora soava como uma aventura inesquecível - similar àquelas narradas por torcedores organizados do futebol de espetáculo (Hollanda, 2008, p. 414-503) - que, para o jovem Expedito, significava o início de sua relação com a Ferroviária. Em muitos casos, seria com a utilizaçấo de caminhôes que clubes viabilizariam suas excursôes, sendo obrigados a irem apenas a cidades próximas. 
Havia equipes que se especializariam na realização de excursôes. Desvinculadas das competiçóes oficiais, elas acumulavam prestígio divulgando seus feitos, algumas vezes, até mesmo pelos jornais. Era o caso do Alfenense, qualificado como "um time que gosta de jogar fora de Belo Horizonte. Náo importa o lugar” (Minas..., 1968). Em outros casos, a perda do campo, em um contexto de transformaçáo urbana e de pressão da especulação imobiliária sobre os terrenos vagos, obrigava alguns clubes a se sustentarem apenas com partidas em canchas alheias e pelo interior do estado, até que conseguissem se organizar para a conquista de um novo espaço de jogo (João Antônio Paranhos Leão; José Fernando Pereira, 2017).

A exemplo do que se via no futebol de espetáculo, a realização de partidas em outras localidades representava oportunidade de afirmaçáo do clube e da comunidade que o suportava. Com equipes formadas, em sua maioria, por trabalhadores em posiçóes subalternas, a participação em tais excursóes propiciava que defendessem o bom nome de sua agremiação, do bairro do qual se originavam e, por consequência, da capital mineira, reafirmando um orgulho operário e suburbano. Era comum a formaçáo de embaixadas que, além de contarem com os integrantes dos clubes, levavam convidados como dirigentes do Departamento de Futebol Amador e da Federação Mineira de Futebol (Uberlândia..., 1949; O Touring..., 1950; O Pitanguí..., 1951) ou representantes da imprensa, todos com as suas despesas custeadas (O Barreiro..., 1952; Pitanguí..., 1960). Um registro que evidencia o esmero dessas associaçōes na formaçáo de suas delegaçōes trata-se da fotografia do conjunto do Alvorada Futebol Clube, em visita à cidade mineira de Monte Carmelo, em 1957.

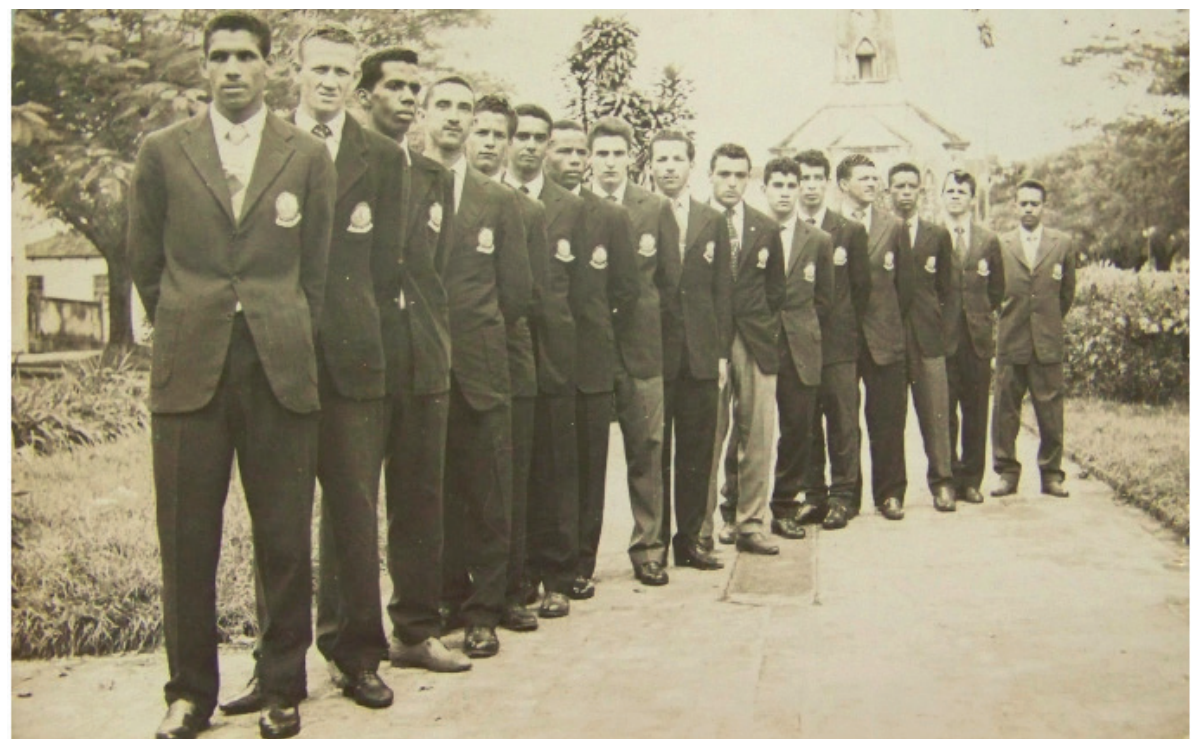

Figura 1 - Delegação do Alvorada Futebol Clube em excursão à cidade de Monte Carmelo, 1957. Acervo: Nilton Graciano da Silva. 
Destacam-se alguns elementos na imagem acima: a escolha da pose, a utilização do paletó com o distintivo do clube bordado, a ambientaçâo no que parece ser uma praça típica do interior mineiro, com uma igreja ao fundo. A montagem da fotografia remete a aspectos importantes das excursóes. A postura dos atletas indica a percepçáo de um papel a se cumprir, de representaçâo da instituição e de todo um cenário esportivo. A preocupaçáo de todos em ostentarem a vestimenta, provavelmente preparada para a ocasião, reforça a ideia da excepcionalidade do evento. A possibilidade de visitar cenários aprazíveis, em localidades distantes, era fator considerado na viagem, em boa parte dos casos, uma das raras oportunidades de turismo desses grupos sociais.

É o que emerge da narrativa de Eliana da Conceição Costa, que nos anos 1970, quando era estudante, ocupou a função de secretária do Avante Futebol Clube, entáo presidido por sua mãe, Maria da Conceição Silva, dona de casa:

Viajava, demais, a gente viajava demais, tanto que a maior parte das cidades que eu conheço foi através do Avante. A gente ia com o time, à Carmópolis, Taquaraçu de Minas, essas fotos que eu te mostrei, Aracruz de Minas. Então a gente ia para Pedro Leopoldo, tudo... Sempre assim, quando acabava o campeonato ele [seu tio] arrumava, entendeu? O campo ficava com o Guaxupé [clube parceiro] e a gente ia com outro time, para outro lugar. Montávamos, montávamos excursão, fazíamos as passagensinhas, não é? Pelo preço da passagem, vendíamos as passagens. Todo mundo ia, o ônibus ia lotado, às vezes tinha vez que a gente ia até com uns dois ônibus de tanta gente que ia. Na época, como existia apenas o Avante, porque o Guaxupé acabou, ficou existindo só o Avante, entấo aonde o Avante ia, ia aquela multidão atrás. (Maria da Conceição Silva; Eliana da Conceição Costa; Carlos Perreira, 2017).

Como contado por ela, as viagens que realizou junto ao Avante marcam algumas de suas principais experiências de turismo pelo interior de Minas Gerais. Assim como ela, vários outros moradores do Aglomerado da Serra, a maior favela de Belo Horizonte, onde está sediada a agremiaçáo, podiam comprar as passagens, que representavam a cotizaçáo do valor do frete de um ônibus, e acompanhar a equipe por diferentes localidades. O interesse da comunidade que se constituía em torno das associaçóes varzeanas pelas excursóes é marcante do papel que as entidades esportivas cumpriam nos bairros. Em meio a seus esforços para a manutenção de um calendário de fins de semanas preenchidos por jogos eram capazes de oferecer outras experiências aos torcedores, o que não era ignorado pelos diretores dos clubes. Tal ponto é abordado na narrativa do dirigente da Associação Esportiva Saudade, Enderson Moretti do Carmo, cujo pai, um policial militar, foi presidente da entidade nos anos 1970 e 1980:

Meu pai, quando falava que tinha excursão, tinha que primeiro selecionar os atletas, não é? Aí atleta queria levar esposa, filha, parente, namorado, essas coisas todas, 
entendeu? Aí o pessoal do bairro: 'tem vaga para ir na excursão?' Mas quando enchia os dois ônibus não tinha mais, não é? E o ônibus antigamente você levava 40 sentados e 40 em pé. Hoje não pode mais... Saia com um ônibus aqui com 50 a 60 pessoas, cada ônibus. Era assim, futebol, o bom, era isso. E interior, só time bom e campo gramado, a gente só ia jogar em campo gramado também, só. Porque sair daqui, que é terra, para jogar no terrão não compensa não, não é? $\mathrm{O}$ pessoal gostava de ir passear e meu pai procurava até uns lugares que tinha cachoeira, um lugar pra tomar banho e tudo. (Enderson Moretti do Carmo, 2016).

A narrativa de Enderson ressalta que além do interesse esportivo, com a busca de um bom campo para as disputas de partidas, a organizaçáo das excursôes envolvia a preocupaçáo por se criar uma alternativa de lazer para a comunidade que se articulava em torno das agremiaçóes, a partir de relaçóes vicinais e de laços de parentesco com os integrantes dos times. Moradores de bairros periféricos da cidade e integrantes das classes trabalhadoras, com pouco acesso ao consumo turístico, tinham nas viagens junto aos times um programa acessível e barato que atendia às suas expectativas de preenchimento do tempo livre com experiências prazerosas e de distensão dos problemas cotidianos. Esse é um aspecto que está marcado na fala de Raimundo Expedito Fernandes, dono de bar, ex-presidente da Associação Ferroviária Esportiva:

Ah... Tinha, sabe por quê? Uma, a própria viagem. A própria viagem, no ônibus, você está deslocando do seu lugar para ir para uma cidadezinha, aquele conhecimento, aquilo não deixava de ser atrativo para um pessoal mais carente, igual você sabe que... Hoje, infelizmente nós estamos tomados de violência e tudo, mas antigamente não era assim, o pessoal gostava mais, tinha mais aquele círculo de amizade, de irmandade, entáo todo mundo gostava, era uma festa. A gente punha os cartazes: 'Domingo Ferroviária vai jogar, tal lugar'. Punha nos bares aqui afora, costumava não ter lugar para ir todo mundo. (Raimundo Expedito Fernandes, 2017).

Sediada na Pedreira Prado Lopes, uma das mais antigas favelas da capital mineira, que nas últimas décadas ficaria estigmatizada pelos altos índices de violência, as excursóes oferecidas pela Ferroviária convertiam-se em uma opção de distração para uma populaçáa alijada de outras experiências de lazer, seja pelo preconceito social e racial, seja pelas restriçóes econômicas. Nessa medida, o circuito da várzea constituíase atravessado por questóes próprias da população e dos lugares nos quais seus clubes estavam enraizados. Apartados do futebol de espetáculo, as agremiaçóes amadoristas se articulavam com outros referenciais culturais e mobilizavam sentidos e expectativas diversos. 


\section{Conclusão}

Ainda que as excursóes como forma de disputas estivessem inseridas em uma longa tradição futebolística mobilizada por décadas por equipes dos circuitos de espetáculo e da várzea, essa fórmula de competição assumia significados variados em meio à experiência. Como indicam os relatos dos integrantes das associaçóes amadoristas de Belo Horizonte, outras práticas se constituíram a partir das viagens empreendidas pelos clubes. Essas dialogavam com a precariedade enfrentada por muitas dessas agremiaçóes, com costumes vinculados a outras expressóes culturais ou com demandas de lazer das comunidades estabelecidas em volta das equipes.

A mobilização de narrativas orais é fundamental para a compreensão desses outros sentidos que se construíam em torno de uma cultura esportiva popular. É a partir dos relatos dos integrantes das agremiaçóes varzeanas que fórmulas de disputa que poderiam ser tomadas como mera reprodução de práticas observadas no futebol de espetáculo ganham sentidos mais abrangentes e se colocam em perspectiva com todo um cenário social e histórico conduzindo a novas apropriaçóes da modalidade e à reivindicação de um protagonismo de trabalhadores e trabalhadoras sobre a organizaçáo de seu tempo livre.

Tal esforço de autonomia na criaçáo de oportunidades de lazer visto no caso das excursóes podia ser observado tanto em outras formas autogeridas de disputa futebolística, a exemplo dos amistosos, festivais, torneios avulsos e jogos festivos, quanto nas demais atividades sociais por eles organizadas, como festas, bailes, piqueniques, etc. Parte de um dos mais potentes fenômenos do associativismo em Belo Horizonte no século $\mathrm{XX}$, esse conjunto de entidades esportivas ainda ocupa um lugar de destaque no cotidiano das regióes periféricas da capital mineira, com a manutençáo de sedes e campos que se articulam ao lazer e à organização comunitária desses lugares.

A possibilidade de se acessar um amplo conjunto de narrativas sobre tal fenômeno passa pelo esforço de preservação e tratamento de acervos de história oral. Ainda que esse material, em grande medida, esteja mantido em instituiçôes de memória e centros de pesquisa, a falta de investimentos dos pesquisadores no seu reuso pode o condenar à condição de "patrimônio silencioso" (Heymann, Alberti, 2018, p. 11-29). A série de entrevistas produzida para o "Inventário do futebol amador em Belo Horizonte", por exemplo, é uma dentre outras coleçôes que reúnem gravaçóes que versam sobre o futebol no Brasil (Hollanda; Ribeiro, 2021, p. 121-147). Muitas possibilidades de apropriação dessas fontes se colocam, incluindo sua articulação a registros orais mais recentes ou o cotejamento com documentos de outras naturezas.

Experiências como o "Inventário do futebol amador em Belo Horizonte", originalmente constituídas para o levantamento de dados para a patrimonializaçáo de uma manifestaçáo cultural, permitem outros desdobramentos na medida em que um acervo de acesso público se constitui. Essa, por si só, é uma iniciativa que possibilita 
o registro do bem. Contudo, a grande expectativa dos grupos envolvidos é de que o reconhecimento definitivo como patrimônio aconteça, uma história ainda em suspenso, que aguarda por ser contada...

\section{Referências}

ALBERTI, Verena. Manual de história oral. Rio de Janeiro: FGV, 2005.

BELO HORIZONTE. Deliberaçóes gerais da 276a sessão ordinária, de 20 de dezembro de 2017. Diário Oficial do Município: Belo Horizonte, ano 26, n. 5449, 9 jan. 2018. Disponível em: http://portal6.pbh.gov.br/dom/iniciaEdicao.do?method=DetalheArtigo\&pk=1189026. Acesso em: 26 abr. 2021.

BELO HORIZONTE. Proposição de Lei no 6/16. Razóes do veto. Diário Oficial do Município: Belo Horizonte, ano 26, n. 4997, 1 mar. 2016. Disponível em: http://portal6.pbh.gov.br/dom/ iniciaEdicao.do?method=DetalheArtigo\&pk=1158793. Acesso em: 26 abr. 2021.

BURLAMAQUI, Luiz Guilherme. A dança das cadeiras: a eleiçáo de Joáo Havelange à presidência da FIFA (1950-1974). Sáo Paulo: USP/Capes: Intermeios, 2020.

CMBH - CÂMARA MUNICIPAL DE BELO HORIZONTE. Pesquisar Proposiçóes. Projeto de Lei n ${ }^{\circ}$ 1.634, de 29 de junho de 2015. Autoria do vereador Adriano Ventura. Autoriza o Executivo a criar o programa de preservaçáo, revitalização e tombamento de Campos de Futebol de Várzea no Município. CMBH, Belo Horizonte, 16 jul. 2015. Disponível em: https://www. cmbh.mg.gov.br/atividade-legislativa/pesquisar-proposicoes/projeto-de-lei/1634/2015. Acesso em: 26 abr. 2021.

DAMO, Arlei Sander. Futebóis - da horizontalidade epistemológica à diversidade política. FuLiA, Belo Horizonte, v. 3, n. 3, p. 37-66, set./dez. 2018.

DAMO, Arlei Sander. O espetáculo das identidades e alteridades - As lutas pelo reconhecimento no espectro do clubismo brasileiro. In: CAMPOS, Flávio de; ALFONSI, Daniela (Org.) Futebol objeto das ciências humanas. São Paulo: Leya, 2014. p. 23-55.

DFA - Legenda do amadorismo de Belo Horizonte. Diário da Tarde, Belo Horizonte, $3^{\circ}$ caderno, p. 9, 12 dez. 1956.

GEERTZ, Clifford. A interpretação das culturas. Rio de Janeiro: Guanabara, 1989.

GOMES, Eduardo de Souza; PINHEIRO, Caio Lucas Morais (Org.). Olhares para a profissionalização do futebol: análises plurais. Rio de Janeiro: Multifoco, 2015.

GUILLEN, Isabel Cristina Martins. Entre bordados, costuras e tambores: a oralidade nos maracatus-nação do Recife, Pernambuco. Apontamentos para pensar o trabalho de campo e a história oral nos inventários do patrimônio imaterial. In: BAUER, Leticia Brandt; BORGES, Viviane Trindade (Org.) História oral e patrimônio cultural: potencialidades e transformaçóes. São Paulo: Letra e Voz, 2018. p. 113-135.

HEYMANN, Luciana; ALBERTI, Verena. Acervos de história oral: um patrimônio silencioso? 
In: BAUER, Leticia Brandt; BORGES, Viviane Trindade (Org.) História oral e patrimônio cultural: potencialidades e transformaçóes. Sáo Paulo: Letra e Voz, 2018. p. 11-29.

HOLLANDA, Bernardo Borges Buarque de. A sagração dos “Reis do Futebol”. In: LOURENÇO, Marcos; ANDREUCCI, Raul; FIGOLS, Victor L. (Org.) Uma década de Ludopédio: dez textos da história da Arquibancada. São Paulo: Editora Ludopédio, 2020. p. 29-40.

HOLLANDA, Bernardo Borges Buarque de. O clube como vontade e representação: o jornalismo esportivo e a formação das torcidas organizadas de futebol do Rio de Janeiro (1967- 1988). Tese (Doutorado em História) - PUC-RJ, Rio de Janeiro, RJ, 2008.

HOLLANDA, Bernardo Borges Buarque de; RIBEIRO, Raphael Rajāo. Museus de fronteira e a musealização do futebol - o lugar da memória futebolística no campo museal brasileiro (anos 1960-1990). Museologia e Patrimônio, Rio de janeiro, v. 14, n. 1, p. 121-147, 2021.

IPHAN - INSTITUTO DO PATRIMÔNIO HISTÓRICO E ARTÍSTICO NACIONAL. Inventário nacional de referências culturais: manual de aplicação. Brasília: Iphan, 2000.

ITAÚNA receberá a visita do tetra-campeão. Diário da Tarde, Belo Horizonte, p. 5, 14 jan. 1949.

LIMA, Veiga. Coluna da Várzea. Diário da Tarde, Belo Horizonte, p. 6, 30 jun. 1965.

LINHALES, Meily Assbú. A trajetória politica do esporte no Brasil: interesses envolvidos, setores excluídos. Dissertação (Mestrado em Ciência Política) - UFMG, Faculdade de Filosofia e Ciências Humanas, Belo Horizonte, MG, 1996.

MASCARENHAS, Gilmar. Entradas e bandeiras: a conquista do Brasil pelo futebol. Rio de Janeiro: EdUERJ, 2014.

MAUSS, Marcel. Ensaio sobre a dádiva: forma e razão da troca nas sociedades arcaicas. In: MAUSS, Marcel. Sociologia e Antropologia. São Paulo: Cosac Naify, 2003. p. 183-314.

MAYOR, Sarah Teixeira Soutto. O futebol na cidade de Belo Horizonte: amadorismo e profissionalismo nas décadas de 1930 e 1940. Tese (Doutorado em Estudos do Lazer) - UFMG, Belo Horizonte, MG, 2017.

MINAS quer ser clube completo. Diário da Tarde, Belo Horizonte, p. 11, 7 nov. 1968.

MYSKIW, Mauro. Nas controvérsias da várzea: trajetórias e retratos etnográficos em um circuito de futebol da cidade de Porto Alegre. Tese (Doutorado em Ciências do Movimento Humano) UFRGS, Porto Alegre, RS, 2012.

O BARREIRO em Patrocinio. Diário da Tarde, Belo Horizonte, p. 5, 18 out. 1952.

O PITANGUI visitará Lagoa Santa. Diário da Tarde, Belo Horizonte, p. 5, 25 out. 1951.

O ROSÁRIO é hexacampeáo do DFA. Diário da Tarde, Belo Horizonte, 2o caderno, p. 13, 1 jun. 1970.

O ROSÁRIO jogará domingo em Pompéu. Diário da Tarde, Belo Horizonte, p. 2, 13 abr. 1963.

O TOURING jogará em São iVcente (sic). Diário da Tarde, Belo Horizonte, p. 9, 9 set. 1950.

PITANGUÍ segue hoje para o Espírito Santo. Diário da Tarde, Belo Horizonte, 2º caderno, p. 5, 12 ago. 1960. 
PORTELLI, Alessandro. Ensaios de história oral. São Paulo: Letra e Voz, 2010.

RIBEIRO, Raphael Rajão. A bola, as ruas alinhadas e a uma poeira infernal: os primeiros anos do futebol em Belo Horizonte (1904-1921). Rio de Janeiro: Drible de Letra, 2018.

QUAL o clube que deseja excursionar? Diário da Tarde, Belo Horizonte, p. 5, mar. 1949.

SANTOS, João Manuel Casquinha Malaia. Revolução Vascaína: a profissionalização do futebol e a inserção sócio-econômica de negros e portugueses na cidade do Rio de Janeiro (1915-1934). Tese (Doutorado em História Econômica) - USP, Faculdade de Filosofia, Letras e Ciências Sociais, São Paulo, SP, 2010.

SANTOS, João Manuel Casquinha Malaia. "Os Leões em África”: futebol e política no Império Colonial Português (1954). Estudos Históricos, Rio de Janeiro, v. 32, n. 68, p. 589-608, set./dez. 2019.

UBERLÂNDIA receberá o Terrestre. Diário da Tarde, Belo Horizonte, p. 4, 25 fev. 1949.

VILARINO, Marcelo de Andrade. Festas, cortejos, procissóes: tradição e modernidade no congado belo-horizontino. Dissertação (Mestrado em Ciência da Religião) - UFJF, Juiz de Fora, JF, 2007.

\section{Fontes orais}

CAMPOS, José Maciel [58 anos]. [jun. 2017]. Entrevistador: Raphael Rajão Ribeiro. Belo Horizonte, MG, 1 jun. 2017.

CARMO, Enderson Moretti do [43 anos]. [dez. 2016]. Entrevistador: Raphael Rajão Ribeiro. Belo Horizonte, MG, 21 dez. 2016.

COLEN FILHO, Jair [68 anos]. [set. 2016]. Entrevistador: Raphael Rajāo Ribeiro. Belo Horizonte, MG, 21 set. 2016.

FERNANDES, Raimundo Expedito [66 anos]. [jan. 2017]. Entrevistador: Raphael Rajāo Ribeiro. Belo Horizonte, MG, 20 jan. 2017.

LEÃO, João Antônio Paranhos [58 anos]; PEREIRA, José Fernando [71 anos]. [jan. 2017]. Entrevistador: Raphael Rajāo Ribeiro. Belo Horizonte, MG, 15 jan. 2017.

MACHADO, Manoel Lúcio [74 anos]; SILVA, Jailson Santos da [40 anos]. [jul. 2018]. Entrevistador: Raphael Rajāo Ribeiro. Belo Horizonte, MG, 12 jul. 2018.

RUFINO, Denerval Martinho [52 anos]; SANTOS, João Pereira dos [73 anos]. [ago. 2017]. Entrevistadores: Marilita Aparecida Arantes Rodrigues; Raphael Rajão Ribeiro. Belo Horizonte, MG, 18 ago. 2017.

SILVA, Maria da Conceição [89 anos]; COSTA, Eliana da Conceição [62 anos]; PEREIRA, Carlos [51 anos]. [mar. 2017]. Entrevistador: Raphael Rajão Ribeiro. Belo Horizonte, MG, 10 mar. 2017. 
Recebido em 30/04/2021.

Aprovado em 17/07/2021.

Fonte de financiamento: nada a declarar.

Conflitos de interesse: entrevistas produzidas como parte das atividades do autor como técnico da Fundação Municipal de Cultura de Belo Horizonte, cargo que ocupa na condição de servidor concursado. 